\title{
MOOD AND MODALITY IN SOEKARNO'S 1955 SPEECH
}

\author{
Syamsidar, Ika Yatmikasari, Dian Nurraachman \\ UIN Sunan Gunung Djati Bandung \\ radismays@yahoo.com, ikayatmikasari@uinsgd.ac.id, diannurrachman@uinsgd.ac.id
}

\begin{abstract}
This research deals with the interpersonal meaning of Soekarno's speech in the first 1955 Asian-African Conference. The study focuses on analysing mood types and choice of modality in that speech. As the speech brought the theme of spirit of solidarity and brotherhood, then this study aims at examining how the choice of mood types and modality represent this theme. To realize this, the framework of Systemic Functional Linguistic (SFL), particularly on mood and modality system by Halliday and Mathiessen (2004), is employed. From the discussion, it is found that clauses are mostly categorized as declarative clauses. It proves that the AsianAfrican Conference was held by the realization of solidarity and brotherhood. The use of declarative clauses indicates the speaker's competences in delivering persuasive speeches by conveying factual information. In addition, it is found that the speaker is neutral and seems to have close relation with the audience. Meanwhile, the use of low degree of modality is helpful to encourage the audience's confidence to act together.
\end{abstract}

Keywords: Systemic Functional Linguistic, Interpersonal Meaning, Tenor of Discourse, Spirit of solidarity and brotherhood.

\section{INTRODUCTION}

The study of discourse by analyzing grammar is common among language researchers. One that is widely used recently is Functional Grammar or Systemic Functional Linguistics (often abbreviated to SFL). SFL itself is a theory of language functions, which is developed by Halliday. Through the work of Halliday and his associates (Halliday and Webster 2002a, 2002b, 2003a, 2003b in Eggins, 2004, p. 1), SFL is increasingly recognized as a very useful descriptive and interpretive framework for viewing language as a strategic, meaning-making resource. In other words, SFL is used to understand the meaning of a text, the purpose of using the text, and the way to value te text. SFL is always related with the meanings of language usage in the textual process of life and how people use language with each other in accomplishing everyday social life. That language is structured to make three kinds of meanings simultaneously. Those three 
are ideational meanings, interpersonal meanings and textual meanings, which are expressed in clause structures. To shorten the scope of the study, the center of the discussion in this research is interpersonal meaning in a speech.

Interpersonal meaning can be said as meaning through which social relations are created and maintained with one another. That meaning, which is efectuated in wordings, is called as mood and modality systems. In line with this, to express interpersonal meaning in a text, a relationship between the semantic organization of interaction and grammatical differences in the mood structure of clauses is established and the functional constituents and their configurations in clauses of different mood types, and the role of modality (modulation and modalization) in interaction are identified (Eggins, 2004, p. 141). Interpersonal meaning concerns with how clauses for different types of interaction are structured and how particular positions (strong, middle or weak) in interactions are taken. The analysis on how interpersonal meaning is used to persuade or to position readers and listeners to take particular stances is also important for developing critical literacy (Droga \& Humprey, 2003, p. 53).

Asian-African Conference is well known as the first biggest conference held by the countries of Asia and Africa continents. Soekarno, the first President of Indonesia, hosted the first Asian-African Conference that was held on April 18 ${ }^{\text {th }} 1955$. It took place in Concordia building and Dana Pensiun building, Bandung, West Java. After the conference, the name of Concordia building was changed into Merdeka building. After the World War II ended, the world was still insecure by the possibility of Cold War era, where the two superpower countries, United States, as the western bloc, and Soviet Union, as the eastern bloc, had attempted to push other countries in this world, including the countries in Asia and Africa continents, to take sides and support each of the blocs. The Cold War was initiated by the difference in capitalism and communism ideology and also by the competition of military tools, space technology and the defense of pacts' establishment (Asian-African Conference Archives, 2014, p. 2)

Soekarno delivered his speech entitled "Let a New Asia and a New Africa be Born" in the opening ceremony of the first Asian-African Conference. The speech becomes the object of this research. In that occasion, the countries of Asia-African continents needed to support each other, have similar status and condition, have similar international problems, and be free from the pressures affected by the cold war. They decided to take action on alleviating tensions as a result of western and eastern blocs' rivalry, which was to strengthen the cooperation among Asian and African countries. Thus, he stated that the main purpose of the conference would not only to ease cold war, but also to evolve struggles against colonialism. (Asian-African Conference Archives, 2014, pp. 2-4)

Soekarno's speech is chosen as the object for this research because it is authentic and powerful. The speech is a persuasive speech in which the speaker has a role as an advocate who tries to make the listeners agree with him/her and to act on that belief (Lucas, 2009, p. 324). Soekarno was one of many people, who had a great influence on this country during Dutch and Japan colonial periods until he endeavoured the independence from the 
colonial's power and declared Indonesian Independence in August 1945. After his heroic attempt, he was appointed as the first president of Indonesia and Moch. Hatta as his vice president.

Based on the description above, the writers are interested in analyzing the interpersonal meaning in that speech and the problems are formulated as follows:

1. How is the tenor of discourse presented in the choice of modality in Soekarno's speech?

2. How are the spirit of solidarity and brotherhood reflected through mood types in Soekarno's speech?

\section{THEORETICAL FRAMEWORK}

SFL is acknowledged as a very useful descriptive and interpretative framework for viewing language as a strategic, making meaning resource (Halliday and Webster 2002a, 2002b, 2003a, 2003b in Eggins, 2004, p. 1). It can be said that SFL is used to understand why a text means as what it does and why it is valued as it is. Those meanings are expressed in clause and described as ideational meaning, interpersonal meaning and textual meaning. The focus of the discussion in this research is interpersonal meaning in a speech.

Interpersonal meaning has an interest in interactions of how the speaker and listener or the writer and reader take their own positions. It is realized through wordings which are called as Mood and Modality in a clause. Text has different purpose as well as entertaining, persuading, giving information, and etc. Interpersonal meaning analysis is mostly aimed to persuade the other or place them in a specific position because the explanation is directly addressed to them to take an action. Besides taking the specific position, another way in persuading the other is through the choosing of Mood and Modality. According to Droga \& Humprey, (2003, p. 58) “Modality expresses a different degrees of probability, usuality, obligation and inclination. By using modality speakers and writers can indicate that they have a particular point of view about something and demonstrate an awareness of other perspective." Thompson adds in his book that Interpersonal meaning is the way the speaker or writer interacts with audience or reader, to establish and maintain relation among them, to influence the audience's and reader's behavior, to express speaker's and reader's viewpoint on things in the world, and to elicit or change listener's and audience's (2014, p. 28).

The word of mood has been emphasized above as the way to analyze a text using interpersonal meaning. Further, it explains about the kind of exchanges in form of clause. Each exchange is depend on the roles and commodity itself so that it bears types of mood. Gerrot \& Wignell states, "There are two main categories in mood types, Indicative mood and Imperative mood, that has their each own functions." (1994, p. 38). Moreover, move constituency is part of the structure clause that cannot be disappeared to keep the argument going is called as Mood. The Mood element consists of two, they are Subject and Finite. The subject is realized by a nominal group and Finite is part of the verbal group. 


\section{METHOD}

This research employs qualitative method that requires textual data collection and examination by using interpretative analysis. Croker said that qualitative research focuses on understanding the process of what's going on in a setting by understanding how the gains were made (Heigham \& Croker, 2009, p. 8). This kind of research often takes a long time as it requires writers to spend time to understand what is going on in order to have a more detailed and intensive focus on each participant. The way of collecting data in qualitative research is formerly textual not numerical; therefore, the writers do an observation by taking notes and using the written transcripts or summaries including questionnaires and diaries. It could not be said that the numerical data will not be used at all, yet it is not used as the central data of the research (Heigham \& Croker, 2009, p. 9).

The data of this study were collected from all clauses in the speech. For mood analysis, all clauses were included and separated based on the types of mood. Meanwhile, modals were collected when they existed in the speech and then categorized based on their degree. After the textual analysis was completed, the analysis was continued to the next stage by relating this finding to tenor of discourse, which is under the same metafunction with mood and modality. The interpretation of the theme of the speech was done to finish data analysis.

\section{DISCUSSION}

The discussion is preceded by textual analysis to examine the aspect of mood and modality of the clauses. It is then followed by the analysis on the findings representing the tenor of discourse and the theme of the speech.

\section{Tenor of Discourse by Means of Modality}

Tenor of discourse is an interpersonal dimension of a clause, or discourse in a broader sense. It refers to whom is taking part in the clause, the nature of the participants, the status and roles of the participants, the kind of relationship obtained among the participants, including permanent and temporary relationship of one kind or another, both types of speech role that they are taking on in the dialogue and the whole cluster of socially significant relationship in which they are involved (Halliday, 1994). Discourse is built by clauses to make the text meaningful and has three elements of different topics, involving field, tenor and mode. Tenor expresses the relation between the speaker and the hearer, in this case between Soekarno and the hearers of his speech by using the status of power and the use of words showing whether the audience likes or dislikes the speaker; the status of intimacy and frequency, which includes the words expressing how much time used during the interaction, and how close the speaker and the hearers are.

\section{Modality of Low Degree}


Modality of low degree covers the words such as can, may, could and might as the modal verbs. The other low degree words in the choice of modality are possibly, perhaps, maybe and sometimes as the modal adverbials, possible as the modal adjectival, possibility as the modal nouns. There are also the choice of modal clause and phrases (henceforth mentioned as interpersonal methapors), I guess (that)... as the modality. These kinds of modality which are found in the speech cover the use of can for 31 clauses, the use of could for 4 clauses, the use of may for 15 clauses, the use of perhaps for about 6 clauses, the use of maybe for about 1 clause, the use of possible for about 4 clauses.

It is clear that the speech delivered by Soekarno mostly employs the use of low modality. Prasetyo argues that the use of low modality may open the possibility to the audiences to doubt the speaker's proposition (2013, p. 102). Since the speech is a kind of persuasive speech, it is important not to let this thing happens, rather than to convince the possibility that may come true in the future. There are some examples of the use of can with different functions, which are explained as follows.

(16) What can we do? The people of Asia and Africa wield little physical power.

(17) We cannot indulge in power politics.

(18) What can we do?

The use of can in datum number 16 indicates Soekarno's doubt of the people in Asia and Africa through the physical power to preserve the world peace. According to Soekarno, without the peace, Asian's and African's independence, rehabilitation and upbuilding of their countries will have no meaning. Then, the use of cannot in datum number 17 shows the delegates' impossibility to strengthen their power even in politics since their statesmanship has no back up of serried ranks of jet bombers and their diplomacy doesn't matter for them. Although those two clauses seem to show their lack in physical and political powers in the first place, the other two following data indicate the opposite meaning. They indeed strengthen the previous clause, although they are also delivered through the low degree of modality.

Soekarno did not let the audience to doubt his utterances about their fate. He convinced them by using the repeated clause of the low commitment, yet with another different function that they have the other ways to do together.

(21) We can mobilise all the spiritual, all the moral, all the political strengths of Asia and Africa on the side of peace.

(22) Yes, we! We, the people of Asia and Africa, 1,400,000,000 strong, far more than half the human population of the world, we can mobilise what I have called the Moral Violence of Nations in favour of peace.

(23) We can demonstrate to the minority of the world which lives on the other continents that we, the majority, are for peace, not for war, and that whatever strength we have will always be thrown on to the side of peace.

The data above show the possibility of Soekarno's suggestions to solve their problems about having no political and physical powers. By using this, Soekarno was neither about to force nor to command the delegates to follow what he had said since the clause was 
placed in the low degree, yet he let the delegates to make a decision or to take an action. Datum number 23 shows that the participants of the conference come from the majority part of the world since the inhabitants of two big continents are gathered and united. Thus, it can make them more powerful in persuading the minority that they exist for peace, not for war, and whatever strength they have and everything they do will put peace on their top priority. The following data are other examples of the speech which shows the audience's possible ability to take an action.

\section{Modality of Medium Degree}

Modality of medium degree covers the words such as will, would, should, is to, was to, and supposed to as the modal verbs. The other words of medium degree in the choice of modality are probably, usually, generally, likely as the modal adverbials, probable and usual as the modal adjectival, and probability as the modal nouns. While the modal clause and phrases cover the word such as, I think (that)..., In my opinion..., It's my likely (that)..., It isn't likely (that)..., and If... then... . This kind of modality which is found in the speech covers the use of will for about 23 clauses, the use of would for 6 clauses, the use of shall for 3 clauses, the use of should for about 2 clauses, the use of usually for about 1 clause, and the use of "I think..." for about 5 clauses.

Those words categorized as medium degree of modality indicate the strong will or determination of the speaker to do something in the future. Some examples of the use of will are presented below.

(62) We hope that the warmth of our welcome will compensate for whatever material shortcomings there may be.

(65) I hope that it will give evidence of the fact that we Asian and African leaders understand that Asia and Africa can prosper only when they are united, and the even the safety of the world at large cannot be safeguarded without a united Asia-Africa.

The two data above are the examples of Soekarno's strong will related to what was going on at that moment. The use of hope before the use of will shows his strong will of what will happen then. Datum number 62 shows Soekarno's determination as the host of the conference that his warm welcome can compensate among the shortcoming materials that may happen. He and the Indonesian people as the hosts of the first intercontinental conference in the world had given their best to create a good memory for the guests regardless some lacks in the service.

Soekarno's next strong will to the conference was shown in datum number 65 . He expected that the Asian and African leaders could understand the importance of being understood and appreciating each other's values, and sympathize with each other's problems. The most important point was that Asia and Africa continents to be united and need to keep the world peace and safe by those mentioned way.

(89) Not material content and meaning only, but also ethical and moral content, for independence without ethics and without morality would be indeed a poor imitation of what we sought. 
The use of medium degree of modality above shows the possibility that will come if they are not giving the material, meaning, ethical and moral contents to their independence. It also aims at leading the delegates to take action in the future in order not to make them experience the bad possibility which is the independence would be a poor imitation of what they have sought.

\section{Modality of High Degree}

Modality of high degree covers the words such as must, ought to, need, has to, and had to as the modal verbs. The other words of high degree in the choice of modality are certainly, definitely, always, never, absolutely, surely and in fact as the modal adverbials, certain, definite, absolutely, necessary and obligatory as the modal adjectival, certainly, necessity, requirement and obligation as the modal nouns. For the modal clause and phrases cover the words such as, I believe (that)..., It is obvious (that)..., Everyone knows (that)..., and Researcher agrees (that).... This kind of modality which is found in the speech covers the use of must for 6 times, the use of need to for 1 clause, and the use of (I/we/there, etc) know for 6 clauses.

The highest degree of modality was used the least by Soekarno in his speech. The word of must represents the highest scale of the modal verbal commitment. Ye argues that it may sign the highest degree of pressure on the other person to carry out a command (2010, p. 149). Thus the use of must is sometimes adopted in a speech to show the speaker's firm determination and to make the audience determined to take action appropriately with certain instructions. The modality can help Soekarno to present his firmdetermination to overcome the difficulties and to invite the delegates to take strong actions to achieve their purpose to hold the conference. The example of the use of strong modality is presented below.

(104) Wherever, whenever, and however it appears, colonialism is an evil thing, and one which must be eradicated from the earth.

The datum above shows the important thing, not only for the audience in the conference, but also for all people living in this world that colonialism is an evil thing. It is a command, a strong determination of Soekarno that wants the delegate to take action appropriately with the instructions, which is eradicating the colonialism from the earth. According to Soekarno, colonialism is a great threat for them beside the war.

\section{Mood Types Indicating Solidarity and Brotherhood}

Mood is the central element in the Mood system that carries interpersonal meaning. There are two main categories in mood types, indicative mood and imperative mood (Halliday \& Mathiessen, 2004). Indicative mood is further specified into declarative and interrogative mood. These types are distinguished based on the position of subject and finite in the mood. The findings in this aspect are interpreted to see how they reflect the theme of the speech. 


\section{Declarative Mood}

Declarative mood is featured by the placement of subject and finite in mood analysis, where the subject is followed by the finite. The number of declarative mood in the speech is 417 clauses out of 449 clauses. There are some considerations why Soekarno chose the declarative mood to become the dominant mood in his speech. It is appropriate to what Ye said in his journal that declarative clauses generally dominate the clauses in a political speech; imperative clauses come next to them; and interrogative clauses are the last choices for the reason that they may make a speech less solemn, less convincing and persuasive (2010, p. 147). The statement that was given by Soekarno towards the other countries' leaders, has a strong impression to convince and persuade them to agree with what he had said. Through the declarative mood, the writer found some information delivered by Soekarno in his speech.

Firstly, the writer found that this Asian African Conference is a realization of solidarity feeling among the countries in Asia and Africa. It is shown in the following data: Table 1: Data on Modality Mood

\begin{tabular}{|l|l|l|l|l|l|}
\hline We & must & look & $\begin{array}{l}\text { to Colombo, } \\
\text { capital of } \\
\text { independent } \\
\text { Sri Lanka, }\end{array}$ & and & $\begin{array}{l}\text { to the Conference of the five } \\
\text { Prime Ministers which was } \\
\text { held there in 1954 }\end{array}$ \\
\hline \begin{tabular}{lll|l|} 
Subjec \\
$\mathbf{t}$
\end{tabular} & Finite & $\begin{array}{l}\text { Predicato } \\
\text { r }\end{array}$ & Adjunct & Adjunct \\
\hline Mood & & Residue & & \\
\hline
\end{tabular}

\begin{tabular}{|l|l|l|l|}
\hline And & the Bogor Conference in December 1954 & showed \\
\cline { 2 - 4 } & Subject & Finite & Predicator \\
\hline Mood & & Residue \\
\hline
\end{tabular}

\begin{tabular}{|c|c|c|c|c|c|c|c|c|}
\hline \multirow[t]{5}{*}{$\begin{array}{l}\text { An } \\
\text { d }\end{array}$} & \multirow[t]{3}{*}{$\begin{array}{l}\text { The } \\
\text { Confe } \\
\text { rence }\end{array}$} & \multirow[t]{3}{*}{$\begin{array}{l}\text { to } \\
\text { whic } \\
\text { h }\end{array}$} & I & \multicolumn{2}{|l|}{ have } & $\begin{array}{l}\text { the honor of } \\
\text { welcoming you } \\
\text { today }\end{array}$ & \multirow[t]{3}{*}{ is } & \multirow{3}{*}{$\begin{array}{l}\text { the } \\
\text { realizatio } \\
\text { n of that } \\
\text { solidarit } \\
\text { y }\end{array}$} \\
\hline & & & $\begin{array}{l}\text { Subj } \\
\text { ect }\end{array}$ & Finite & $\begin{array}{l}\text { Predi } \\
\text { cator }\end{array}$ & Complement & & \\
\hline & & & \multicolumn{2}{|c|}{ Mood } & \multicolumn{2}{|c|}{ Residue } & & \\
\hline & \multicolumn{6}{|c|}{ Subject } & Finite & $\begin{array}{l}\text { Comple } \\
\text { ment }\end{array}$ \\
\hline & \multicolumn{7}{|l|}{ Mood } & Residue \\
\hline
\end{tabular}

The data above tell us that before they had the Asia and Africa Conference, they had held two meetings in Colombo and Bogor. However, only five countries attended the meetings. Then those five Prime Ministers thought that it would be better if they held a bigger 
meeting with more delegates from two big continents that were placed in the same position as an effect of the world war between the Western and Eastern blocs. The meeting would also strengthen the relation between the countries in two big continents, namely Asia and Africa. Solidarity is the unity (as of a group or class) that produces or is based on community of interests, objectives, and standards. In this case, Asia and Africa countries had the same objectives, which was to be free from the world war problem, and to strengthen their relationship especially in politic and economic sectors.

Soekarno also used the word brotherhood to make them sure that they were all relatives in the continents of Asia and Africa. The sample data are presented as follows.

Table 2: Data on Modality of Brotherhood

\begin{tabular}{|l|l|l|}
\hline This conference & is not & to oppose each other, \\
\hline Subject & Finite & Complement \\
\hline Mood & Residue \\
\hline
\end{tabular}

\begin{tabular}{|l|l|l|}
\hline it & is & a conference of brotherhood \\
\hline $\begin{array}{l}\text { Subjec } \\
\mathbf{t}\end{array}$ & Finite & Complement \\
\hline Mood & & Residue \\
\hline
\end{tabular}

Beside trying to convince them by using the word "brotherhood", the data above also show that the conference did not intend to oppose the other countries who had different principles from them. Even if they had intended not to stand on neither Eastern nor Western bloc, they did not try to oppose the difference of religion or club or ethnic or race. Yet, they only decided to take action to be natural and there was no relation between their behavior and those differences.

\section{Imperative Mood}

The number of imperative mood existed in the speech were 15 clauses out of 449 clauses. It was less than the declarative one; yet, it also has an important role in analyzing the interpersonal meaning. Imperative mood conveys two types of message, involving a command for others to do something or an invitation for others to do something or to achieve something together. The dominant pattern of the imperative mood in the speech is the use of the word "let". It is intended to invite the others to do something together thus to persuade the delegates to do something and achieve something together. In the speech, there are three imperative moods that use the same pattern and have the same function as shown below.

Table 3: Data on Imperative Mood

\begin{tabular}{|c|c|c|c|c|c|}
\hline \multirow[t]{3}{*}{ And } & let us & \multicolumn{2}{|c|}{ remember, } & Sisters and Brothers, & that for the sake of all that, \\
\hline & Subject & Finite & $\begin{array}{l}\text { Predicato } \\
\mathrm{r}\end{array}$ & Complement & Complement \\
\hline & \multicolumn{2}{|l|}{ Mood } & \multicolumn{3}{|l|}{ Residue } \\
\hline
\end{tabular}




\begin{tabular}{|l|l|l|}
\hline $\begin{array}{l}\text { we Asians and } \\
\text { Africans }\end{array}$ & must be & united \\
\hline Subject & Finite & Predicator \\
\hline Mood & & Residue \\
\hline
\end{tabular}

\begin{tabular}{|c|c|c|c|c|c|c|c|c|c|c|}
\hline \multicolumn{2}{|c|}{ Be guided } & \multirow{2}{*}{$\begin{array}{l}\text { by hopes and } \\
\text { determinatio } \\
\text { n } \\
\text { Complement }\end{array}$} & \multicolumn{2}{|c|}{ be guided } & \multirow[t]{2}{*}{$\begin{array}{l}\text { by } \\
\text { deal } \\
\text { s }\end{array}$} & \multirow[t]{2}{*}{ and } & \multirow{2}{*}{$\begin{array}{l}\text { yes, } \\
\text { Polarity } \\
\text { Ad. }\end{array}$} & \multicolumn{2}{|c|}{ be guided } & \multirow{2}{*}{$\begin{array}{l}\text { by } \\
\text { dreams } \\
\text { ! } \\
\text { Comple } \\
\text { ment }\end{array}$} \\
\hline $\begin{array}{l}\text { Fini } \\
\text { te }\end{array}$ & $\begin{array}{l}\text { Pre } \\
\text { dica } \\
\text { tor }\end{array}$ & & $\begin{array}{l}\text { Fin } \\
\text { ite }\end{array}$ & $\begin{array}{l}\text { Predi } \\
\text { cator }\end{array}$ & & & & $\begin{array}{l}\text { Fini } \\
\text { te }\end{array}$ & $\begin{array}{l}\text { Predi } \\
\text { cator }\end{array}$ & \\
\hline $\begin{array}{l}\text { Mo } \\
\text { od }\end{array}$ & \multicolumn{2}{|c|}{ Residue } & \multicolumn{2}{|c|}{ Mood } & $\begin{array}{l}\text { Resi } \\
\text { due }\end{array}$ & & & $\begin{array}{l}\text { Mo } \\
\text { od }\end{array}$ & \multicolumn{2}{|c|}{ Residue } \\
\hline
\end{tabular}

In formal speech, the speaker usually uses the phrase 'Ladies and Gentlemen' to greet the audience; yet, Soekarno didn't use it. It can be seen from the previous data above that he greeted the audience with the words 'Brothers and Sisters'. He aimed at shortening the relation to the delegates of the conference, and regarded them as their relatives. He asked them to remember that they were in the same continents of Asia and Africa, and had to be united to strengthen their relation in facing the international problems. In terms of unity, he got them to be guided by hopes, determination deals, and dreams.

\section{Interrogative Mood}

Another type of mood used in the speech is interrogative. There were 17 clauses containing interrogatives mood out of 449 clauses. The arrangement of mood and residue element are oppose to the declarative. It is employed as the expression of question, which requires an answer to make the exchange successfully. Yet, this public speech doesn't seem to seek an answer since it is to inform the listeners about how to act. The example of interrogative datum is presented below.

Table 4: Data on Interrogative Mood

\begin{tabular}{|l|l|l|l|}
\hline $\begin{array}{l}\text { Are } \\
\text { not }\end{array}$ & these aims & $\begin{array}{l}\text { mentione } \\
\text { d }\end{array}$ & $\begin{array}{l}\text { in the letter of invitation to which you } \\
\text { responded? }\end{array}$ \\
\hline $\begin{array}{l}\text { Finit } \\
\text { e }\end{array}$ & Subject & Predicator & Adjunct \\
\hline Mood & Residue \\
\hline
\end{tabular}

By using the interrogative mood above, Soekarno didn't look forward to the answer, but it aimed at attracting the delegates' attention as well as emphasizing his point to make the audience think and rouse their passion for overcoming the current difficulties. 
Soekarno also wanted to convince the delegates that they had received the letter of invitation to come to the Conference. The only ones who got the letter were the countries which stood on Asia and Africa continents. In addition, he also wanted to preserve and stabilize peace in the world during the cold world war that happened while the conference was going on.

\section{CONCLUSION}

The speech's tenor of discourse reveals Soekarno's intention to be neutral. He didn't show his like or dislike toward the audience or the conference. Indeed, he tended to ask the delegates to stand on his side. By using the word that presented him as the host of the conference, he showed that he was more powerful than the delegates attending the conference at that time. The intimacy between him and the delegates was shown by his use of Sisters and Brothers to greet the delegates. It made them look closer than any other audience of a meeting.

The low of modality is usually used to make the audience doubt what the speaker is saying; yet, in this case it helps the speaker to convince the delegates that they have possibility to take action or to do something together. The use of medium degree in the speech was to deliver his strong determination and desire to do an action in the future and also to confirm that more actions will be definitely taken in the future. It led the delegates to agree with what Soekarno said. The last is the use of high degree modality to show the speaker's firm determination and to make the audience determined to take appropriate action with certain instructions and achieve their goals.

By analyzing the mood analysis of the speech, it proves that the main reason of holding the conference was to keep solidarity and brotherhood. It can be seen through Soekarno's use of declarative and imperative clauses. Besides that, the interrogative clauses convinced the delegates that they gathered in that conference to strengthen their spirit of solidarity and brotherhood against the cold world war.

The use of declarative mood in the speech was to show Soekarno's competencies in delivering persuasive speech by giving information about who Soekarno and the audiences were, what their purpose to hold the conference was and what they had to do at that time and in the future. The use of imperative mood was intended to invite the others to do something together; thus, to persuade the delegates to do something and achieve something together. The interrogative mood was used in the speech to inform the listeners about how to act. It aimed at not only attracting the delegates' attention, but also emphasizing his purpose to make the audience think and rouse their passion for overcoming the current difficulties. However, this speech is a kind of persuasive speech in which the speaker tried to persuade the hearers. This study provides some guidelines for readers that declarative clauses are recommended to convey as many messages as possible to the audience and convince the audience with facts. An appropriate application of imperative clauses are useful in making persuasion and suggestion. 


\section{REFERENCES}

(2014). Asian-African Conference Archives. National Archives of the Republic of Indonesia. Droga, L., \& Humprey, S. (2003). Grammar and meaning. Australia: Target Texts.

Eggins, S. (2004). An introductions to systemic functional linguistics 2nd edition. London: Continuum.

Gerrot, L., \& Wignell, P. (1994). Making sense of functional grammar. Australia: New South Wales: Gerd Stabler.

Halliday, M.A.K. (1990). An introduction to functional grammar (1 $1^{\text {st }}$ edition). London: Hadder Arnold.

Halliday, M. A., \& Matthiessen, C. M. (2004). An introduction to functional grammar (3 ${ }^{\text {rd }}$ edition). London: Hadder Arnold.

LUCAS, S. E. (2009). The art of public speaking. New York: McGraw-Hill.

Merriam-Webster. (n.d.). Retrieved from https://www.merriam-webster.com

Ye, R. (2010). The interpersonal metafunction analysis of Barrack Obama's victory speech. English Language Teaching Vol. 3, No. 2; June 2010, 146-151. 